The Anatomy of Fake News 
The publisher and the University of California Press Foundation gratefully acknowledge the generous support of the Anne G. Lipow Endowment Fund in Social Justice and Human Rights. 


\title{
The Anatomy of Fake News
}

\author{
A CRITICAL NEWS \\ LITERACY EDUCATION
}

\section{Nolan Higdon}

曰 UNIVERSITY OF CALIFORNIA PRESS 
University of California Press

Oakland, California

\section{(C) 2020 by Nolan Higdon}

Cataloging-in-Publication Data is on file at the Library of Congress.

IS B N 978-0-520-34786-1 (cloth : alk. paper)

IS BN 978-o-520-34787-8 (pbk. : alk. paper)

IS BN 978-0-520-97584-2 (ebook)

Manufactured in the United States of America

$\begin{array}{lllllllll}28 & 27 & 26 & 25 & 24 & 23 & 22 & 21 & 20\end{array}$

$\begin{array}{llllllllll}10 & 9 & 8 & 7 & 6 & 5 & 4 & 3 & 2 & 1\end{array}$ 